This item was submitted to Loughborough's Research Repository by the author.

Items in Figshare are protected by copyright, with all rights reserved, unless otherwise indicated.

\title{
Derivatives as weapons of mass deception and elite contestation: the case of FIAT
}

PLEASE CITE THE PUBLISHED VERSION

http://dx.doi.org/10.4324/9781315773476

PUBLISHER

Routledge

VERSION

AM (Accepted Manuscript)

\section{PUBLISHER STATEMENT}

This work is made available according to the conditions of the Creative Commons Attribution-NonCommercialNoDerivatives 4.0 International (CC BY-NC-ND 4.0) licence. Full details of this licence are available at: https://creativecommons.org/licenses/by-nc-nd/4.0/

\section{LICENCE}

CC BY-NC-ND 4.0

\section{REPOSITORY RECORD}

Lagna, Andrea. 2019. "Derivatives as Weapons of Mass Deception and Elite Contestation: The Case of FIAT". figshare. https://hdl.handle.net/2134/22511. 
Derivatives as weapons of mass deception and elite contestation: the case of FIAT and equity swaps

\section{Andrea Lagna}

Critical scholars on finance - especially those who contribute to the interdisciplinary debate on financialization - have advanced fascinating insights into the complex world of derivatives. ${ }^{1}$ In so doing, they have questioned orthodox perspectives on derivatives according to which these instruments reflect the true essence of modern finance in its pursuit of market efficiency (Greenspan 2002). In contrast, critical researchers have shown how derivatives are inherently linked to capitalist exploitation and unstable financial cultures. The debate has taken two directions. On the one hand, some studies have explored how derivatives affect the present-day financialized capitalism. For instance, Bryan and Rafferty (2006) argue that derivatives represent a third degree of separation in the ownership of capital after the joint-stock form. If we take the case of a stock option, this instrument entitles the holder only to the price change in the underlying shares but not to the actual shares. This implies that derivatives holders become less concerned with events occurring in the field of production. Building on such argument, Wigan (2009) has shown that derivatives are like artifices of indifference because they make financialization disengage from the 'real' productive economy. On the other hand, scholars in the social studies of finance (SSF) field have uncovered the socio-cultural embeddedness of derivatives markets, agents and devices. For example, in a remarkable study, MacKenzie and Millo (2003) have captured the performativity of the Black-Scholes-Merton formula for pricing options through an ethnographic study of the Chicago Board Options Exchange. They have shown that the empirical success of this theory was due to the fact that traders used it in their activities on the pits. In short, options theory shaped the market in a performative manner.

Thus, critical scholars have proposed alternative views on derivatives that innovatively challenge the assumption that these contracts can produce a complete market in the sense given by Arrow and Debreu (1954). ${ }^{2}$ This is 
certainly a laudable achievement. However, despite their original insights, critical studies fall short of providing the appropriate analytical tools to explore the specificities of derivatives excesses in distinct contexts such as the Italian political economy. This is the case for two main reasons. First, analyses that contextualize derivatives within the abstract contours of modern capitalism are geared towards explaining how these instruments expand the frontiers of global capital accumulation. Yet, they focus too much on the abstract features of finance-dominated growth and ultimately ignore what Nölke, Heires, and Bieling (2013) define as the politics of financialization, namely: the actual actors and power struggles constructing financial developments on the ground. Thus this literature glosses over how the global expansion of derivatives - or, more generally, financialization - essentially depends on the distinct conflicts in which key social forces are involved. Second, the politics of financial innovation could be addressed through the heuristic framework of SSF. After all, scholars in this specialism seek to show how financial markets and models - far from being efficient and objective - are inherently driven by changing socio-cultural norms and conventions. Hence, at a first glance, this perspective could provide a useful understanding of financial agents and their pragmatic initiatives. However, SSF conflate actors and technologies within small-scale networks, often relying on the notion of performativity to explain how markets - together with the subjects involved - are produced through discursive reiteration. Consequently, this approach fails to appreciate the wider political-economic environment in which actors are situated and how key social forces might deploy derivatives for strategic purposes.

Against the shortcomings of the critical literature on derivatives, this chapter focuses particularly on the cultural-performative perspective and argues that the latter exemplifies a 'cultural turn' in political economy that does not account for the tactical scenario constraining - or enabling - the realisation of any given performance (Sum and Jessop 2013). Pushed to its logical conclusion - a path which, as we will see, Foucauldian-inspired studies have taken (Aitken 2007; de Goede 2005; Langley 2009) - performativity implies that differences amongst agents are mostly irrelevant since it is through their combined action that financialized norms are performed and reproduced. The 
paradox is that, although the role of agency is recognized, the latter nonetheless lacks differential political-economic and socio-cultural leverage. In such analytical context, it is difficult to capture 'who', 'how' and 'why' adopts financialized practices - such as derivatives -differentially and tactically.

Premised on this critique, my chapter re-introduces active agency to the analytical picture in order to uncover the power struggles underpinning the growth of derivatives in the Italian context. By drawing on insights from Political Marxism (Knafo 2002, 2010, 2013) and Critical Institutionalism (Konings 2008, 2010b, 2011), this work conceives social construction as a fluid phenomenon in which historical agents interact with each other through the mediation of continuously renegotiated practices. In this historicized framework, people are seen as exerting power by exploiting extant materialities and meanings in the attempt to enhance their positions over others. However, far from structurally reifying human reality, contested praxis opens up opportunities to further transform existing inter-subjective rules.

Through these lenses, the study focuses on how Italian neoliberal-minded technocrats and centre-left politicians (henceforth neoliberal reformists) attempted to challenge the country's old political and business elites over the course of the 1990s. ${ }^{3}$ They did so by implementing a market-oriented modernization of Italian capitalism, a crucial component of which was the shareholder-oriented transformation of the country's financial system - that is banking, securities markets and corporate governance (Cioffi and Hopner 2006; Deeg 2005). The work focuses particularly on the 'enabling' (Konings 2010b) character of these pro-market reforms and how they provided opportunities for the Agnellis - the founding family and historical blockholders of the car-manufacturer FIAT - to do exactly the opposite of what neoliberal reformists hoped for: to secure ownership over their business empire through the strategic use of equity swaps.

The chapter proceeds in six steps. First, it advances a critique of culturalperformative approaches in critical research on finance. Second, it comments briefly on derivatives as essential tools of tactical accounting deception. Third, 
it explores the political-economic and socio-cultural context in which neoliberal reformists emerged and began to put forward the necessity to modernize the domestic financial system from the mid-1990s onwards. Fourth, it focuses on the specificities of the corporate governance reform. Fifth, it examines the FIAT case and how the Agnelli family avoided diluting their ownership and control by using equity swaps. Finally, the chapter concludes in support of undertaking a cultural turn in the financialization debate that elucidates the political-strategic environment in which financial innovation thrives.

\section{Underperforming cultures of finance}

Critical research on finance is currently experiencing a cultural revival. Rather than focusing on the material and quantitative reality - as in the case of Régulation School (Boyer 2000), Post-Keynesian economics (Stockhammer 2008) and Marxist political economy (Lapavitsas 2009) - culture-oriented studies explore financial markets as domains constituted by conventional habits and discourses. In this regard, SSF scholars are doing much to uncover the construction of modern finance as experienced by practitioners in their daily activities (Beunza and Stark 2012; MacKenzie 2006; Preda 2009; Zaloom 2006). Far from depicting financial developments as abstract entities, they examine the microcosm of actors, technologies, no-nonsense practices and bricolage-like innovation producing such phenomena. For instance, Mackenzie and Millo (2003) deploy the notion of performativity to examine the extent to which options pricing theory was an empirical success not because it discovered pre-existing patterns, but because it performed - that is, moulded - markets in a way that increasingly fitted the model. ${ }^{4}$

Expanding on this notion of performing discourses and practices, other culture-oriented scholars such as De Goede (2005), Langley (2009) and Aitken (2007) draw on Foucault (1977) and Butler (1997) to explore how actors collectively create the dominant discourse of modern finance by performing it - that is, carrying it out - in their daily habits. This is obviously a more dense and pervasive understanding of performativity that incorporates society at a macro-level rather than being confined within the small-scale 
boundaries of trading floors, as it is the case with SSF. For instance, Langley (2009) examines how people choose to invest in the stock market as a rational form of saving compared to using more traditional accounts at thrift institutions. Hence, by becoming a normal and largely unquestioned ensemble of everyday practices, present-day finance - with its complex and highly marketized activities - turns into an overarching apparatus that spreads its disciplinary power deep inside subjective identities. Following a similar understanding of discursive production in everyday life, de Goede (2005) examines the events concerning the enactment of the 2000 Hedge Fund Disclosure Act in the US, following the collapse of the hedge fund Long Term Capital Management in 1998. She argues that this regulatory framework did not represent a ban on hedge funds, but a depoliticization and normalization of their operations. In other words, authorities created a legitimate discursive environment for hedge funds to operate. Furthermore, the philosophy behind - such as the assumptions of derivatives trading as an efficient riskmanagement practice - represents the major contemporary discourse that legitimizes contemporary finance as a highly profitable business.

Thus, as these studies show, cultural-performative approaches are on the rise. This is a much-needed development in critical scholarship on finance for at least two reasons. First, it shows the importance of focusing on human agency as the architect and interpreter of hegemonic discourses (Amoore et al. 2000:62-63). Second, it strongly asserts the significance of discursive phenomena in a field overly dominated by a materialist bent. However, as this chapter claims, such growing interest for the inter-subjective processes of meaning creation tends to obscure the strategic environment in which actors experience their existence. In fact, as Konings (2010b:63) notes, culturefocused studies properly explore the semiotic constitution of subjectivities. Yet, what they fail to deploy is an understanding of discursive not only as shaping actors' identities but also as enabling their action. In particular, the extensive use of performativity analysis has the unfortunate effect of flattening social relations by transferring power from historically specific forces to the general discursive space the features of which constrain everyone in similar ways. ${ }^{5}$ As a result of this - when applied to the Italian case or elsewhere - 
cultural-performative studies end up disregarding the fact that key actors do not merely adopt derivatives because the dominant financialized discourse condition them. On the contrary, they often do so to advance their objectives against other agents in a tactical manner. In other words, people aim at achieving context-specific aims by managing ever-present unintended events and by attempting to influence commonly shared norms.

To rectify such limitations in cultural studies of finance, this chapter calls for a more historicized approach to financial innovation and - in our specific case derivatives. It advances a critical method that aims at capturing the tactical and conflictual character of people's discursive and material interaction. ${ }^{6}$ Significantly, this perspective does not conceptualize power as structured in and through the discourses of financialization. On the contrary, power is introduced at the level of agency once discursive structures are recast as mediating social relations amongst actors (Knafo 2010: 504). In other words, actors interact with each other by negotiating complex discourses and materialities, continuously exploiting - or more simply, relating to - these interconnecting architectures. This radically alters our understanding of power, which becomes the agential ability to construct discursive norms and gain leverage in a particular scenario. In other words, power is interpreted at a pragmatic level where some agents experiment with extant institutions whilst others abandon their search for empowering themselves and live reality according to existing norms. Yet, far from reifying human reality, the process of structuration is constantly open to conflictual relations and transformation.

The following sections deploy this method to investigate first how Italian neoliberal-minded reformists attempted to challenge the country's old political and business elites by implementing a market-oriented modernization of Italian capitalism and, in particular, a shareholder-oriented transformation of the country's financial system. Next, the study focuses on the Agnelli family and their tactical use of derivatives. First, however, I reconsider derivatives as instruments of accounting dissimulation. 


\section{A brief excursus: financial derivatives as weapons of mass deception}

Derivatives-like contracts existed for a long time (Swan 1999). Yet, it is only in the late-nineteenth-century US that contracts on the future shipment of wheat were standardized into so-called futures and systematically disconnected from the final delivery of the underlying commodity. This innovation generated a surge in speculative activities that clashed with the interests of farmers and the rising populist movements (Geisst 2002: 4; Goodwyn 1976). At this point, facing agrarian forces, representatives of commodity exchanges recast derivatives trading and its speculative activities as essential resources for the management of business risk. In the end, this idea was institutionalized in such terms and the modern practices of derivatives-based risk management was eventually consolidated (Levy 2006).

Still, as long as the majority of derivatives were traded on organized commodity exchanges, derivatives-based techniques did not reveal their full potential. It was only in the early 1970 s - once American power relations were turning in favour of finance (Gowan 1999; Panitch and Gindin 2008) - that Chicago exchanges successfully lobbied for the introduction of financial derivatives on their trading pits (MacKenzie and Millo 2003; MacKenzie 2006). In this regard, the discipline of financial economics provided scientific legitimacy by describing derivatives as tools that protect investors from the risk of financial market volatility (Wigan 2009).

During the 1970s, derivatives trading expanded but several regulatory uncertainties between the Commodity Futures Trading Commission (CFTC) and the Security Exchange Commission (SEC) still remained (Markham 2002: 88-89). Once these issues were solved in the early 1980s, derivatives grew in size and rate of innovation, becoming essential components of American financial power in the global economy (Konings 2006: 508-509). Three markets were particularly remarkable: index derivatives, asset-backed securities and, above all, swaps. According to the mainstream narrative, swaps emerged as useful instruments through which investors hedged their risk exposures to interest rates and exchange rates (Markham 2002: 192). 
That was true to a certain extent. But, at a non-rhetorical level, swaps became also the perfect tools that companies, financial actors and governments can use to avoid regulation and to window-dress their books. As Partnoy (2009:46) explains in reference to the case of the historic investment bank Bankers Trust:

Merton Miller's insight implied that companies would do swaps not necessarily because swaps allocated risk more efficiently, but rather because they were unregulated. They could do swaps in the dark, without the powerful sunlight that securities regulation shined on other financial instruments. And here was the crucial point: to the extent companies and their financial officers could use custom-tailored swaps to avoid regulation or to hide risks, Bankers Trust's profits from selling swaps to those companies might not disappear so quickly. Corporate treasurers hoping to benefit from such swaps would pay a premium - it wasn't their money, after all - if the swaps were structured in a way that created more opportunity for profit, but hid the risks from their bosses.

Over the course of the 1980s, as derivatives trading expanded, other societies also began to adopt these very useful 'weapons of mass deception' (Dunbar 2006; Norris 2013). ${ }^{7}$ How and why were they used in the Italian context? Let us look particularly at the case study of FIAT and equity swaps. ${ }^{8}$

\section{Modernizing Italian capitalism}

In the early 1930s, Adolf Berle and Gardiner Means (1968: 8) famously described the most crucial development of American capitalism as 'the dissolution of the old atom of ownership into its component parts, control and beneficial ownership' They argued that the consolidation of the joint-stock company implied a separation of corporate ownership and control such that a myriad of dispersed owners - the shareholders - emerged. Whilst diversifying their investment portfolios across several firms listed on the stock exchange, these shareholders exerted almost no control over the managers who ran 
day-to-day operations. The condition was such that the latter were potentially able to form a 'technostructure' through which they could consolidate their power over other social groups (Galbraith 2007). The research by Berle and Means became very influential and many studies focused on the various practices - such as independent boards of directors and the market for corporate control - that could make managers more accountable to shareholders (Grossman and Hart 1988; Jensen and Meckling 1976).

Contrary to the American case but like other European countries, the Italian case was historically characterized by a relatively limited separation of ownership and control. In fact, Italy's economic history evolved through an ownership liaison between private business oligarchies and the expanding public enterprise (Segreto 1998). So the Italian story was not one in which dispersed shareholders should develop mechanisms to make strong managers accountable (Roe 1994). Rather, the problem concerned instead the presence of strong blockholders - state and oligarchs - influencing the activities of weak managers against the interests of unprotected minority shareholders (Melis 2000: 354).

Particularly from the late 1950s onwards, two intense forces - public and private capitalism - marked with their respective logics and points of friction the Italian political-economic arena. On the one hand, governing political parties - the alliance between Christian Democrats and Socialists - were concerned with controlling and driving the expansion of public enterprise as a way to guarantee their 'self-reproduction' (Bianchi 1987). In so doing, the dynamics of so-called Partitocrazia came into being, a condition in which the ruling parties eliminated any possibility for alternation in power and consolidated their clout over the state and society at large (Pasquino 1995). They politicized appointments in nearly every state-owned institution - from industry to banks, via schools, hospitals and post offices - through widespread networks of patronage and factional loyalty (Ginsborg 2001:139142). On the other hand, private business oligarchs necessitated of adequate solutions to protect their ownership structures against the expansion of the state-owned apparatus. As Barca (2001:44-46) shows, the architectures of 
ownership in the private industry were so complex that they secured control even when the ownership quotas of blockholders decreased as a result of business expansion. Two mechanisms were indispensable for such condition to be achieved. The first one was the pyramidal group, in which two or more companies were legally separated but controlled by a holding through ownership chains. For instance, at the top of the pyramid sat the family-owned holding, whilst all the other companies had a mere subsidiary role. Of course, the voting rights of minority shareholders were dispersed over a large number of these subsidiary firms. The blockholders' shares were instead concentrated in the holding at the top of the pyramid. Second, besides these pyramidal constructions, cross-shareholding alliances were cultivated to further secure a narrow separation of ownership and control. In addition to these two mechanisms, several other artifices were adopted such as: including insurance companies as part of the pyramidal group in order to inject liquidity whenever it was needed; proxy votes with no obligations by the proxies to the principals; or the possibility for the management to refuse new shareholders as a protective measure against takeovers. Of course, the inefficient stock exchange and the absence of a transparent corporate governance regime completely sealed the power of blockholders over minority shareholders.

It was the imperative to hold such high degrees of ownership concentration in the hands of few actors - whilst at the same time maintaining open channels for external funding and corporate growth - that encouraged blockholders to gather around several gravitational centres of Italian capitalism (Segreto 1997: 649). Such meeting places were also crucial to cultivate the equilibria between private and state ownership. The most important hub was the Milanbased investment bank Mediobanca that - due to the peculiar public-private nature of its shareholding syndicate - mediated the conflictual dynamics between the oligarchies and the expanding state-owned enterprises. Above all, Mediobanca became the financial engineer for large private companies by providing funding strategies that also guaranteed the oligarchic structures of ownership and control (Battilossi 1991; Segreto 2008). As authoritative journalists labelled it, Mediobanca was the so-called salotto buono of Italy: the 
exclusive saloon where a clutch of business and political echelons managed tacitly the existing shareholding alliances (Economist 2010).

This private-public liaison reached its most collusive and corrupt essence during the 1980s. It is at this point that a pro-market technocratic elite - based primarily at the Bank of Italy and the Ministry of Treasury (Deeg 2005: 528) launched a critique of the Italian political economy that exalted the benefits of reducing public debt (Giavazzi and Spaventa 1988), privatizing the stateowned sector (Goldstein 2003; Scognamiglio 1990) and, a few years later, modernizing the domestic financial system in favour of shareholder value (Amatori and Colli 2000; Associazione Disiano-Preite 1997; Lazonick and O'Sullivan 2000). Through their neoliberal critique of the Italian 'mixed' economy, technocrats aimed at undermining the foundations upholding conservative politics-cum-business affairs. To begin with, downsizing and privatizing the public enterprise implied hindering the normal reproduction of Partitocrazia that, as already mentioned, depended on the clientelistic exploitation of the state-owned apparatus. In addition, the objective of reducing public debt entailed removing government expenditure as an essential tool of mass consensus. In fact, especially during the Craxi administration (1983-1987), public spending was instrumental to creating an atmosphere of enrichissez-vous amongst large strata of privileged groups (Pasquino 2000: 79).

Regarding instead private capitalist oligarchies, the shareholder-oriented transformation of the financial system implied an attack on their concentrated structure of ownership and control. Especially during the 1980s, companies had turned towards equity finance after comprehensive strategies of industrial and financial restructuring (Amatori and Colli 2000; Graziani 1998). However, the stock-market expansion did not signal concrete transformation in the traditional strategies of ownership concentration. Indeed, it was the result of the long-established practice of pyramid-building through which major groups increased the number of related spin-offs listed on the stock exchange (Deeg 2005:528). Hence, more transparent rules of corporate governance, as well as an efficient and liquid equity markets, would have ensured equality of rights 
amongst shareholders and less opportunities to weave cross-shareholding alliances. In a word, a growing call for meritocracy in corporate ownership and control endangered the traditional practices of private capitalism in Italy (McCann 2000:49-50).

The neoliberal ideas put forward by technocrats became influential in the late 1980s and early 1990s, when the process of European integration revealed a new impetus with the launch of the single market and the project of monetary union. In a context where the political-economic establishment and the popular discourse were supportive of Europe in a general sense (Quaglia 2011), crucial reforms were introduced such as the removal of capital controls, the transformation of public banks into joint-stock companies and the independence of the central bank. ${ }^{9}$ Above all, technocrats gained considerable power over the policy contents during the intergovernmental conference (IGC) on EMU. In February 1992, by adhering to the convergence criteria for joining EMU, they imposed an external discipline on the country's vested interests and their reproductive capacities (Dyson and Featherstone 1996). Of course, technocrats gradually advanced practices that disturbed the reproduction of the status quo in Italian capitalism. Yet, these tactics were insufficient to dismantle long-established power structures, both in their political and business dimension. In reality, it was only when the bribery scandals of Tangentopoli exploded in February 1992 that the traditional political system - with most part of its business connections - began to collapse. ${ }^{10}$ From this moment onwards, technocrats together with the centreleft coalition of the Olive Tree - who got to power in 1996 - captured the executive power and embarked on an extensive season of liberalizing reforms with the objective of joining EMU in 1999 (Cioffi and Hopner 2006; Deeg 2005). In particular, they normalized labour relations in order to curb inflation and cut down government expenditure to stabilize public finance (Sbragia 2001:81). Furthermore, they undertook a far-reaching privatization programme (Goldstein 2003) and - more importantly for our purposes - they attempted to transform Italian finance in line with the ideology of shareholder value. This was done in order to eradicate the oligarchic structure of Italian business. Let us now focus on the main traits of this financial modernization. 


\section{The shareholder-oriented transformation of Italian corporate governance}

The shareholder-oriented transformation of Italian finance entailed constructing a regime of corporate governance that favoured the dispersion of ownership as well as the development of a liquid and efficient stock market. In other words, this strategy was coherent with the objective of diluting the longlasting oligarchic nature of Italian business in the attempt to render it more reactive to global market inputs and innovation. As Massimo D'Alema - a leading figure of the centre-left - explained, 'we still have not done enough to create a proper financial market [...] We do not have guarantees for small shareholders, no rules for public companies' (Betts and Blitz 1997).

As Lazonick and O'Sullivan (2000) show, the ideology of shareholder value originated in the historical evolution of American corporate capitalism, particularly once the latter fully unleashed the dynamics of financialization after the 1970s crisis. At its core stands a large and transparent stock market that functions as a source of business investment and corporate control for public companies. In a given company, dispersed and legally protected shareholders - primarily institutional investors - are the ultimate owners. These actors delegate to the board of directors the task of monitoring the managers who are in charge of directing the company's day-to-day activities e.g. investment, production, pricing, marketing and so on. In other words, managers are accountable to the board of directors and, ultimately, to the shareholders who have the voting power to select the board. The crucial point of this shareholder-oriented regime of corporate governance is the following: once the management fails to deliver profits and dividends, shareholders exercise their power at the general meeting and vote for a new board of directors and management. However, in reality, shareholders are too fragmented to exercise this control vis-à-vis the management and the passive board of directors. In this case, the market for corporate control enters the picture. Shareholders could show their dissatisfaction by selling the company's shares and, in turn, depressing the share price accordingly. At this 
point, the company turns into an attractive target for takeover strategies. Potential bidders buy up shares of the target company in order to take control of the board and replace the top management. In this sense, the market for corporate control disciplines the managers by pushing them to maximize shareholder value, otherwise they would succumb to hostile takeovers (Clarke 2007:130-131).

Applied to Italy, this simple story concerning shareholder value promised a profound impact on the national business establishment. To be exact, as already seen, the historical rationale of Italian capitalism was rather different than the Anglo-American experience. In Italy, strong blockholders - such as the oligarchs and the state - influenced the activities of collusive managers against the interests of unprotected minority shareholders. Yet, as McCann (2000: 49-50) clearly explains:

A properly functioning capital market with strong institutional investors would ensure a greater equality of rights between shareholders, thus undermining the capacity of [blockholders] to gain a dominant control of firms despite possessing only minority holdings. The marginalization of cross-shareholding alliances would greatly increase the feasibility of suc- cessful takeover bids and thus intensify the pressure on management to deliver higher profitability and larger dividends [...] This would serve to enhance economic efficiency and contribute to a growing meritocracy of ownership and control.

Italian liberal intellectuals had for a long time advanced the importance of reforming Italian company law to prevent the formation of blockholders (Marchetti 2001). Yet, despite these influential opinions, it was particularly during the 1990s that the political-economic and cultural climate turned conducive to introducing the institutions and discourses of shareholder value. The major push to corporate governance reforms came from the process of privatization. Indeed, the 1994 privatization law was important in two respects. ${ }^{11}$ First, by introducing norms that protected minority shareholders in the soon-to-be privatized companies, neoliberal reformists were free to 
experiment without any particular resistance from the blockholders of existing private companies. Second, it created a contrast between privatized companies and other listed firms that did not conform with a transparent governance structure (Enriques 2009: 7).

Concrete action towards a comprehensive reform of corporate governance was taken in 1996, when the Parliament delegated to the executive the power to transfer several EU directives into the Italian legislation. ${ }^{12}$ Besides importing the European Capital Adequacy Directive and the Investment Services Directive, the Parliament gave the government also the task to consolidate financial market regulation into a single law. ${ }^{13}$ According to the provision, the government had to 'amend the laws on listed corporations with specific regard to the board of internal auditors, minority shareholder rights, shareholder voting agreements and intra-group transactions, with a view to strengthen the protection of savings and minority shareholders' (Enriques 2009: 9). Hence, in order to undertake this task, the Treasury established a technical committee under the leadership of Director-General Mario Draghi. This decision was controversial. In fact, influential voices complained that such an important reform was being implemented behind closed doors and away from a wider political debate (Scalfari 1997). Hence, an enquiry was opened at the lower house of the Parliament in October 1997 (Lonardi 1997). The 'Draghi' reform - as it was soon nicknamed - met the opposition of the centre-right and Confindustria, the major business association. In particular, the issue of mandatory takeover bids was the most controversial point (Puledda 1998a; Repubblica 1998; Scalfari 1998). However, in spite of such resistance, the reform was eventually passed in late February 1998 and came to be known as the consolidated law on finance (Testo Unico della Finanza, TUF). ${ }^{14}$

TUF envisioned a new regime of corporate governance in favour of shareholder value. It was an 'omnibus law that aggregated, reformulated and renewed virtually all civil and criminal rules pertaining to capital markets, securities management, institutional investors, brokerage services, public offerings and rules for listed joint stock corporations' (Deeg 2005:534). Amongst the key points, the following ones were particularly significant. ${ }^{15}$ 
First, the reform increased the protection of minority shareholders through a tighter regulation of shareholder agreements. The latter had to be notified publicly; they could not exceed three years; they were no longer valid in the case of takeover bids (Amatori and Colli 2000:43). These measures hit the core of those cross-shareholding practices which blockholders traditionally used to consolidate their relations of mutual trust (McCann 2000:51-52). Furthermore, mandatory takeover bids became compulsory once exceeding 30 per cent of the total capital (Puledda 1998b). Second, minority shareholders - identified according to a minimum ownership ranging from 1 to 10 per cent of the outstanding shares - obtained more governance rights. Third, representation of minority shareholders was mandatory at the audit board, the internal body in charge of auditing activities. Finally, the reform reinforced the power of Commissione Nazionale per la Società e la Borsa (CONSOB), the national stock market authority. CONSOB was put in charge of supervising investor protection, the efficiency and transparency of the stock market, and the effective functioning of the market for corporate control. CONSOB could now request ad-hoc information and undertake on-site inspections concerning shareholder agreements and blockholding practices.

Needless to say, the Draghi reform emphasized the importance of the stock market in a country where equity finance had traditionally played a marginal role. ${ }^{16}$ In fact, whilst the Draghi committee was drafting the reform of corporate governance, the various national stock exchanges merged in the Milan-based

Borsa which was then privatized and began to operate as Borsa Italiana in January 1998 (Borsaltaliana 1999). In a context where declining interest rates made government securities a less attractive form of investment for the wider public people looked at the stock market with enthusiasm (Betts 1997). In particular, the flotation of the recently privatized Telecom Italia mirrored the frenzy for the dot-com bubble in the United States (Rampini 1997).

\section{How to hedge the risk of ownership dilution: FIAT and equity swaps}

How far did corporate governance reforms transform Italian capitalism into a shareholder democracy? How did the oligarchies react to such a different 
regulatory environment? It is now time to look at a unique case of market manipulation that shows how the new corporate governance regime did not simply constrain business oligarchies, but also enabled them to use the new institutions and discourses in a strategic sense. The following case concerns the car-manufacturer FIAT and its founding family: the Agnellis. ${ }^{17}$

In a context of dramatic crisis, FIAT entered a three-year convertible bond of $€ 3$ billions with a consortium of eight banks in 2002. ${ }^{18}$ As a hybrid of debt and equity, this instrument allowed the holder to convert the bond into the issuing company's stocks - or cash of equal value - at an agreed-upon price. The FIAT's convertible bond had a maturity date that was set for September 2005. More importantly, in the case of insolvency, the bond was to be converted into FIAT shares at a price of $€ 10.3$. This conversion implied dramatic consequences for the ownership structure of FIAT. In fact, the $30.6 \%$ ownership of the holding Ifil Investments in FIAT - Ifil was controlled by IFI (62\%), which was in turn entirely owned by the Agnelli family through the partnership Giovanni Agnelli \& Co. S.a.p.az. - would have been diluted of roughly one third in favour of the banks.

In fact, the worst happened. FIAT announced on April 26, 2005 - less than five months before maturity - that the convertible bond was going to be converted into shares. In other words, this was a historic event for Italian capitalism: the Agnelli empire was on the verge of collapse after a century of oligarchic control over FIAT. However, the family found an astute strategy to remain in the 'driving seat' (Economist 2005). The very same day when the bond conversion was announced, Exor Group - a Luxembourg-based financial holding which was controlled by the Agnelli family via IFI - entered into an equity swap contract with Merrill Lynch International on $€ 90$ millions of FIAT ordinary shares. ${ }^{19}$ An equity swap would normally be settled in cash. However, the contract between Exor Group and Merrill Lynch included a clause that allowed also the physical settlement. Neither the investing public nor CONSOB were informed about this operation, except for a communiqué on August 24, 2005 in which Ifil and Giovanni Agnelli \& Co. told CONSOB that no particular manoeuvre on FIAT shares was occurring. In this dispatch, Ifil 
and Giovanni Agnelli \& Co. nonetheless stated that they intended to keep control of FIAT (Boffano and Griseri 2010).

How does an equity swap specifically work? This is a derivative contract in which future cash flows are agreed to be exchanged between two counterparties - respectively known as the equity amount payer and the equity amount receiver - at specific interim dates or in a single maturity date in the future. The equity amount payer transfers to the equity amount receiver the positive difference between i) the spot value of the equity and ii) the initial reference price agreed on the contract. On the contrary, the equity amount receiver pays any potentially negative difference between these two elements. On top of this dimension which is typical of an equity future, the two parties enter into a further reciprocal obligation that is the swap element: the payer transfers to the receiver also the dividends generated by the equities in question, whilst receiving an interest rate (e.g. LIBOR or EURIBOR) on the notional capital equal to the value of equities at the moment of the agreement.

In our case, the equity amount payer Merrill Lynch would have paid the equity amount receiver Exor Group the positive performance in relation to the initial reference price of the underlying equity plus the dividends. Merrill Lynch would have instead received from Exor Group the negative performance together with an interest rate on the notional capital - which is equal to the initial reference price multiplied by the number of underlying shares. After this agreement was signed, Merrill Lynch started to hedge by buying the underlying shares. In line with this hedging strategy, Merrill Lynch bought shares on the stock market from April to June 2005, accounting for the $15 \%$ of daily trading and $10 \%$ of FIAT's voting capital. Accordingly, FIAT's share price rose from $€ 4.8$ to $€ 6$. In accordance with the Italian regulation on takeovers, Merrill Lynch communicated that its ownership had reached the $2 \%$ threshold but never $5 \%{ }^{20}$ How was it possible to hide the remaining share of FIAT's voting capital that Merrill Lynch owned?

The investment bank never exceeded the $5 \%$ level by 'swapping out' - that is, entering a reverse contract compared to the one with Exor Group - with two 
other counterparts, ING bank and Cater Allen International, for a total of $6.5 \%$ of FIAT's voting shares. Being in this case the equity amount receiver, Merrill Lynch entered these secondary equity swaps with ING and Cater Allen by transferring to the latter the underlying shares as credit risk collaterals. ${ }^{21}$ Hence, both banks also declared they went beyond the $2 \%$ threshold. In other words, this is all the market and CONSOB perceived during the period between April and September: three global investment banks merely exceeded the $2 \%$ threshold in FIAT's ownership.

In September 2005, when FIAT's convertible bond finally expired, Merrill Lynch had already settled in cash the secondary equity swaps with ING and Cater Allen. At this point, the investment bank bought back the collaterals that were then transferred to Exor Group. Indeed, as already mentioned, the equity swap contained the clause of physical settlement. Eventually, Exor Group bilaterally sold these shares to Ifil, of which participation in FIAT's ownership went simultaneously down to the $30 \%$ threshold - due to the convertible bond's agreement - and up the same level as a result of the shares received by Merrill Lynch and its complex equity-swap strategy.

At that time, few voices denounced the Agnelli's abuse of the most basic rules of shareholder democracy (Bragantini 2005; Penati 2005). In fact, the authorities intervened very late and the case gained momentum only in the early 2007, when the Milan court began investigating the affair and CONSOB imposed sanctions on the top management of IFI and Ifil (Repubblica 2007). The main issue at stake concerned the communiqué that Ifil and Giovanni Agnelli \& Co. released in late August 2005. Indeed, the latter did not disclose information about the equity swap between Exor Group and Merrill Lynch, therefore constituting an infringement of the current regulation on market communication and market manipulation. ${ }^{22}$ In the end, the investigation was transferred to the court of Turin, the city where the Agnelli family is based. Here, the top management of IFI and Ifil was first acquitted in December 2010 and eventually condemned in February 2013 (Boffano and Griseri 2010; Repubblica 2013). In the meantime, the case sparked a debate within CONSOB about how to prevent bidders from accumulating undisclosed equity 
positions through cash-settled derivatives. These discussions led CONSOB to modify the rules of transparency concerning potential shareholdings with cash settlement. Investors are now obliged to communicate also their positions on cash-settled derivatives. ${ }^{23}$

\section{Conclusions}

This chapter has argued that cultural-performative studies on financialization do not take into account the strategic scenario constraining - or enabling the realisation of any given agential performance (Sum and Jessop 2013). Paradoxically, although this approach could provide a prolific conceptualization of financial actors and their tactics, it is still unable to properly capture the power struggles underpinning the global expansion of derivatives and financialization more broadly - an aspect that brings culturalperformative research closer to more abstract-structuralist views on derivatives (Bryan and Rafferty 2006; Wigan 2009). To rectify such limitations, the chapter has aimed at bringing agency back to uncover the conflictual relations shaping the use of derivatives in the Italian context. To do so, it has drawn on insights from Political Marxism (Knafo 2002, 2010, 2013) and Critical Institutionalism (Konings 2008, 2010b, 2011) with the objective of emphasizing how inter-subjective meanings not only influence actors' identities but also enable them to act.

By using this method, the study has examined the shareholder-oriented modernization of Italian finance as a strategy that neoliberal reformists implemented in order to challenge old political and business elites during the 1990s (Cioffi and Hopner 2006; Deeg 2005). After this, the work has focused on how these pro-market reforms enabled the Agnelli family to secure ownership over FIAT through the tactical use of equity swaps.

\section{Endnotes}

${ }^{1}$ The financialization debate examines the increasing role of financial 
motives, financial markets, financial actors and financial institutions in the operation of the domestic and international economies' (Epstein 2005: 3). Useful introductions to the debate include special issues of: Economy \& Society, 29 (1) 2000; Competition \& Change, 12 (2) 2008 and 13 (2) 2009.

${ }^{2}$ According to this orthodox view, myriads of derivatives contracts - both plain vanilla and more complex synthetic combinations - enable all possible future states of the world to be captured by being traded on the basis of risk. For a critical examination of this thesis, see Wigan $(2008,2009)$.

3 The terms 'neoliberal-minded', 'neoliberal' or 'neoliberalism' denote the ideology according to which 'human well-being can best be advanced by liberating individual entrepreneurial freedoms and skills within an institutional framework characterized by strong private property rights, free markets, and free trade' (Harvey 2005:2). Of course, the emphasis on the free market and the retreat of the state is a rhetorical matter. In reality, neoliberal forces capture state institutions and exploit them to secure their discipline over society (Konings 2010a). 'Technocrat' refers here to experts in specific fields e.g. economics, law and so on - who apply their knowledge to government affairs either as technical advisers or unelected decision-makers (Silva 2008). ${ }^{4}$ Language philosopher John L. Austin (1962) initially developed the concept of performativity. He described as performative those 'self-actualizing' statements that do not simply state facts, but enact what they name in the first place (e.g., a promise). Callon (1998) later explored the performativity of economics and inspired SSF scholars to deal with such notion in their work.

${ }^{5}$ Compare Foucault (1977:176), who sees the latter as a 'multiple, automatic and anonymous' network.

6 This proposition has some similarities with the work of Sum and Jessop (2013; see also this volume). However, whereas they build on a critical-realist ontology and epistemology, this chapter maintains a subjective-constructivist stance that is grounded in Hegelian phenomenology and dialectics. For an entry point on this philosophical position and its significance within historicalmaterialist studies, see Fraser (1997) and Knafo (2002).

${ }^{7}$ Warren Buffett (2003) once defined derivatives as 'financial weapons of mass destruction'. In contrast, this study highlights their potentials for 
deceiving and concealing accounting rules.

${ }^{8}$ This work deals specifically with FIAT. Two other important examples of derivatives excesses in Italy are: (1) the Italian government's use of derivatives markets to comply with the Maastricht criteria; (2) local authorities' adoption of interest rate swaps to circumvent the European Stability and Growth Pact. For a full analysis of these other two case studies, see Piga (2001), Dunbar (2000) and Lagna (2013).

${ }^{9}$ About these reforms, cf. respectively ministerial decree 27 April 1990 at http://www.dt.tesoro.it/export/sites/sitodt/modules/documenti it/prevenzione $r$ eati finanziari/normativa/DM-27-aprile-1990.pdf; law no. 218, 30 July 1990, available at: http://www.normattiva.it; law no. 82, 7 February 1992, available at: http://www.normattiva.it (all retrieved 22 June 2014).

${ }^{10}$ About these reforms, cf. respectively ministerial decree 27 April 1990 at http://www.dt.tesoro.it/export/sites/sitodt/modules/documenti it/prevenzione $r$ eati finanziari/normativa/DM-27-aprile-1990.pdf; law no. 218, 30 July 1990, available at: http://www.normattiva.it; law no. 82, 7 February 1992, available at: http://www.normattiva.it (all retrieved 22 June, 2014).

${ }^{11}$ Cf. law no. 474, 30 July 1994, at http://www.normattiva.it (retrieved 22 June 2014).

${ }^{12}$ Cf. law no. 52, 6 February 1996. At: http://www.normattiva.it/ (retrieved 22 June, 2014).

${ }^{13}$ Cf. ibid., capitolo II, art. 21, 4. Available at: http://www.normattiva.it/. The Capital Adequacy Directive (Directive 93/6/EEC, 15 March 1993) and the Investment Service Directive (Directive 93/22/EEC 10 May 1993) were imported into Italian law through the law decree no. 415, 23 July 1996. At: http://www.normattiva.it/ (all retrieved 22 June 2014).

${ }^{14}$ Cf. law decree no. 58, 24 February 1998. At: http://www.normattiva.it/ (retrieved 22 June 2014).

${ }^{15}$ Unless otherwise referenced, the following summary of the 'Draghi' reform is based on Enriques (2009:9-11).

16 It is important to note that when the 'Draghi' reform was enacted, shareholder value had become a major objective also in Europe. About the market-oriented transformation of European corporate control, see van 
Appeldoorn and Horn (2007). This dimension was embedded in the wider process of European financial market integration (Bieling 2003; Mügge 2008). ${ }^{17}$ For histories of the Agnelli family and FIAT's crucial role in Italian capitalism, see Clark (2011) and Castronovo (2005).

${ }^{18}$ Unless otherwise referenced, my analysis of the FIAT-equity swap events is based on de Nova et al. (2010: 9-11). This is the transcript of a debate with Italian experts on derivatives, including Giovanni Portioli from the Insider Trading Department of CONSOB.

${ }^{19}$ Exor Group merged with Ifil and IFI in February 2009, forming Exor S.p.A. Today, Exor is the key investment holding that controls FIAT S.p.A. and FIAT Industrial. See: http://www.exor.com/ (retrieved 22 June 2014).

${ }^{20}$ Cf. law decree no. 58, 24 February 1998, articles 102-112. At: http://www.normattiva.it/ (retrieved 22 June 2014).

${ }^{21}$ As explained in de Nova (2010: 9-10), each participant in an equity swap is subject to a credit risk exposure to the counterpart. If the underlying share rises in price, the equity payer must make a payment in relation to the increase. Conversely, if the underlying share falls, the equity payer is entitled to a payment. Regarding these secondary equity swaps with ING and Cater Allen, Merrill Lynch was the equity swap receiver rather than the payer, as occurred with the principal swap with Exor Group. Thus, when the stock price fell, there was credit risk to the equity payer (ING and Cater Allen) and vice versa. Hence, both ING and Cater Allen mitigated such credit risk by asking the underlying shares as collateral in line with their price movements. For this reason, Merrill Lynch regularly lodged FIAT shares with ING and Cater Allen.

${ }^{22}$ Cf. law decree no. 58, 24 February 1998, articles 114 (par. 7) and 187-ter. At: http://www.normattiva.it/ (retrieved 22 June 2014).

23 Cf. regulation no. 17919, 9 September 2011; at: http://www.consob.it/main/aree/novita/consultazione emittenti 20110909 esiti .htm (retrieved 22 June 2014).

\section{References}


Aitken, R. 2007. Performing Capital: Toward a Cultural Economy of Popular and Global Finance. New York: Palgrave Macmillan.

Amatori, F., and A. Colli. 2000. Corporate Governance: The Italian Story. Fontainebleau: European Institute of Business Administration (INSEAD).

Amoore, L. et al. 2000. "Paths to a Historicized International Political Economy." Review of International Political Economy 7(1):53-71.

Arrow, K., and G. Debreu. 1954. "Existence of an Equilibrium for a Competitive Economy." Econometrica 22(3):265-90.

Associazione Disiano-Preite, ed. 1997. Rapporto Sulla Società Aperta. Cento Tesi per La Riforma Del Governo Societario in Italia. Bologna: ॥ Mulino.

Austin, J. L. 1962. How to Do Things with Words. Oxford: Clarendon Press.

Barca, F. 2001. "Compromesso Senza Riforme Nel Capitalismo Italiano." in Storia del Capitalismo Italiano, edited by F. Barca. Roma: Donzelli.

Battilossi, S. 1991. "L'Eredità Della Banca Mista. Sistema Creditizio, Finanziamento Industriale E Ruolo Strategico Di Mediobanca 19461956." Italia Contemporanea (185):627-53.

Berle, A. A., and G. C. Means. 1968. The Modern Corporation and Private Property. San Diego: Harcourt.

Betts, P. 1997. "The Bourse. Market 'Half the Size It Should Be'." Financial Times, December 10.

Betts, P., and J. Blitz. 1997. "At the Head of Italy's Table The FT Interview: Massimo D'Alema." Financial Times, December 22.

Beunza, D., and D. Stark. 2012. "From Dissonance to Resonance: Cognitive Interdependence in Quantitative Finance." Economy and Society 41(3):383-417.

Bianchi, P. 1987. "The IRI in Italy: Strategic Role and Political Constraints." West European Politics 10(2):269-90.

Bieling, H. J. 2003. "Social Forces in the Making of the New European Economy: The Case of Financial Market Integration." New Political Economy 8(2):203-24.

Boffano, E., and P. Griseri. 2010. "Processo Ifil-Exor, Tutti Assolti 'Non C'è Stato Aggiotaggio.'" La Repubblica, December 21. Retrieved 22 June 2014 (http://torino.repubblica.it/cronaca/2010/12/21/news/efilexor_tutti_assolti-10442945/). 
Borsaltaliana. 1999. Fatti E Cifre Della Borsa Italiana, 1998. Retrieved 22 June 2014

(http://www.borsaitaliana.it/borsaitaliana/statistiche/tuttelestatistiche/fatt iecifre/fattiecifre1998.htm).

Boyer, R. 2000. "Is a Finance-Led Growth Regime a Viable Alternative to Fordism? A Preliminary Analysis." Economy and Society 29(1):111-45.

Bragantini, S. 2005. "Se l'Equity Swap Dribbla La Comunicazione." LaVoce.info, September 25. Retrieved 22 June 2014 (http://archivio.lavoce.info/articoli/pagina1756.html).

Bryan, D., and M. Rafferty. 2006. Capitalism with Derivatives. A Political Economy of Financial Derivatives, Capital and Class. Basingstoke: Palgrave Macmillan.

Buffett, W. E. 2003. "Chairman's Letter." Berkshire Hathaway Annual Report 2002. Retrieved 22 June 2014 (http://www.berkshirehathaway.com/2002ar/2002ar.pdf).

Butler, J. 1997. Excitable Speech: A Politics of the Performative. New York: Routledge.

Callon, M., ed. 1998. The Laws of the Markets. Oxford: Blackwell.

Castronovo, V. 2005. FIAT: Una Storia del Capitalismo Italiano. Milano: Rizzoli.

Cioffi, J. W., and M. Hopner. 2006. "The Political Paradox of Finance Capitalism: Interests, Preferences, and Center-Left Party Politics in Corporate Governance Reform." Politics and Society 34(4):463-502.

Clark, J. 2011. Mondo Agnelli: Fiat, Chrysler, and the Power of a Dynasty. Hoboken: John Wiley \& Sons.

Clarke, T. 2007. International Corporate Governance. A Comparative Approach. London, New York: Routledge.

Deeg, R. 2005. "Remaking Italian Capitalism? The Politics of Corporate Governance Reform." West European Politics 28(3):521-48.

De Nova, G., Fusco, E., Girino, E., Onado, M., Portale, G. B., Portioli, G., Righi, S., Rimini, E. 2010. "Quale Futuro per I Derivati Finanziari?" Transcription of the Debate on "I Contratti Derivati" by Girino, E., Borsa Italiana S.p.A., November 11. Retrieved 22 June 2014 (http://www.ghidiniassociati.it/Quale\%20futuro\%20per\%20i\%20derivati\%20finanziari\%20\%20Trascrizione\%20Dibattito.pdf).

Dunbar, N. 2000. Inventing Money: The Story of Long-Term Capital Management and the Legends behind It. New York: Wiley. 
Dunbar, N. 2006. "Risky Finance: Weapons of Mass Deception." uuw.nickdunbar.net. Retrieved 22 June 2014

(http://www.nickdunbar.net/articles-and-reviews/risky-finance-weaponsof-mass-deception/).

Dyson, K., and K. Featherstone. 1996. "Italy and EMU as a 'Vincolo Esterno': Empowering the Technocrats, Transforming the State." South European Society and Politics 1(2):272-99.

Economist, The. 2005. "Still In the Driving Seat." The Economist, October 13. Retrieved 22 June 2014 (http://www.economist.com/node/5026856).

Economist, The. 2010. "Ties That Bind Mediobanca's Grip on Generali Shows the Effects of Cross-Shareholdings." The Economist, March 18. Retrieved 22 June 2014 (http://www.economist.com/node/15731244).

Enriques, L. 2009. Modernizing Italy's Corporate Governance Institutions: Mission Accomplished? Brussels: European Corporate Governance Institute (ECGI).

Epstein, G. A. 2005. "Introduction: Financialization and the World Economy." in Financialization and the World Economy, edited by G. A. Epstein. Northampton, MA: Edward Elgar Pub.

Foucault, M. 1977. Discipline and Punish. The Birth of the Prison. New York: Vintage Books.

Fraser, I. 1997. "Two of a Kind: Hegel, Marx, Dialectic and Form." Capital \& Class 21(1):81-106.

Galbraith, J. K. 2007. The New Industrial State. Princeton: Princeton University Press.

Geisst, C. R. 2002. Wheels of Fortune. The History of Speculation from Scandal to Respectability. Hoboken: Wiley.

Giavazzi, F., and L. Spaventa, eds. 1988. High Public Debt: The Italian Experience. Cambridge: Cambridge University Press.

Ginsborg, P. 2001. Italy and Its Discontents, 1980-2001. London: Penguin Books.

De Goede, M. 2005. Virtue, Fortune, and Faith. A Genealogy of Finance. Minneapolis: University of Minnesota Press.

Goldstein, A. 2003. Privatization in Italy 1993-2002: Goals, Institutions, Outcomes, and Outstanding Issues. Munich: CESifo Group.

Goodwyn, L. 1976. Democratic Promise: The Populist Moment in America. Oxford: Oxford University Press. 
Gowan, P. 1999. The Global Gamble: Washington's Faustian Bid for World Dominance. London: Verso.

Graziani, A. 1998. Lo Sviluppo dell'Economia Italiana. Dalla Ricostruzione Alla Moneta Europea. Torino: Bollati Boringhieri.

Greenspan, A. 2002. "International Financial Risk Management." The Federal Reserve Board. Remarks by Chairman Alan Greenspan before the Council on Foreign Relations, Washington, D.C. Retrieved 22 June 2014

(http://www.federalreserve.gov/boarddocs/speeches/2002/20021119).

Grossman, S. J., and O. D. Hart. 1988. "One Share-One Vote and the Market for Corporate Control." Journal of Financial Economics 20:175-202.

Harvey, D. 2005. A Brief History of Neoliberalism. Oxford: Oxford University Press.

Jensen, M. C., and W. H. Meckling. 1976. "Theory of the Firm, Managerial Behaviour, Agency Costs and Ownership Structure." Journal of Financial Economics 3(4):305-60.

Knafo, S. 2002. "The Fetishizing Subject in Marx's Capital." Capital and Class 76:145-75.

Knafo, S. 2010. "Critical Approaches and the Legacy of the Agent/Structure Debate in International Relations." Cambridge Review of International Affairs 23(3):493-516.

Knafo, S. 2013. The Making of Modern Finance. Liberal Governance and the Gold Standard. Abingdon: Routledge.

Konings, M. 2006. "The Rise of American Finance. Agency, Institutions and Structural Power from Colonial Times to the Globalization Era." York University, Toronto, PhD Thesis, NR29503.

Konings, M. 2008. "The Institutional Foundations of US Structural Power in International Finance: From the Re-Emergence of Global Finance to the Monetarist Turn." Review of International Political Economy 15(1):35-61.

Konings, M. 2010a. "Neoliberalism and the American State." Critical Sociology 36(5):741-65.

Konings, M. 2010b. "The Pragmatic Sources of Modern Power." European Journal of Sociology 51(1):55-91.

Konings, M. 2011. The Development of American Finance. Cambridge: Cambridge University Press. 
Lagna, A. 2013. "Deriving a Normal Country. Italian Capitalism and the Political Economy of Financial Derivatives." PhD Thesis, Brighton: University of Sussex.

Langley, P. 2009. The Everyday Life of Global Finance: Saving and Borrowing in Anglo-America. Oxford: Oxford University Press.

Lapavitsas, C. 2009. "Financialised Capitalism: Crisis and Financial Expropriation." Historical Materialism 17:114-48.

Lazonick, W., and M. O'Sullivan. 2000. "Maximizing Shareholder Value: A New Ideology for Corporate Governance." Economy and Society 29(1):13-35.

Levy, J. I. 2006. "Contemplating Delivery: Futures Trading and the Problem of Commodity Exchange in the." The American Historical Review 111(2):307-35.

Lonardi, G. 1997. "La Camera Frena II Tesoro Sulla Riforma Delle Società." La Repubblica, October 24. Retrieved 22 June 2014 (http://ricerca.repubblica.it/repubblica/archivio/repubblica/1997/10/24/la -camera-frena-il-tesoro-sulla-riforma.html).

MacKenzie, D. 2006. An Engine, Not a Camera: How Financial Models Shape Markets. Cambridge, MA: MIT Press.

MacKenzie, D., and Y. Millo. 2003. "Constructing a Market, Performing Theory: The Historical Sociology of a Financial Derivatives Exchange." The American Journal of Sociology 109(1):107-45.

Marchetti, P. 2001. "Diritto Societario E Disciplina Della Concorrenza." in Storia del Capitalismo Italiano, edited by F. Barca. Roma: Donzelli.

Markham, J. W. 2002. A Financial History of the United States. From the Age of Derivatives into the New Millennium (1970-2001). Armonk: M. E. Sharpe.

McCann, D. 2000. "The 'Anglo-American' Model, Privatization and the Transformation of Private Capitalism in Italy." Modern Italy 5(1):47-61.

Melis, A. 2000. "Corporate Governance in Italy." Corporate Governance 8(4):347-55.

Mügge, D. K. 2008. "Widen the Market, Narrow the Competition: The Emergence of Supranational Governance in EU Capital Markets." University of Amsterdam, Faculty of Social and Behavioural Sciences.

Nölke, A., M. Heires, and H. J. Bieling. 2013. "Editorial: The Politics of Financialization." Competition \& Change 17(3):209-18.

Norris, F. 2013. "Wielding Derivatives as a Tool for Deceit." The New York Times, June 27. Retrieved 22 June 2014 
(http://www.nytimes.com/2013/06/28/business/deception-byderivative.html).

Panitch, L., and S. Gindin. 2008. "Finance and American Empire." Pp. 17-47 in American Empire and the Political Economy of Global Finance, edited by L. Panitch and M. Konings. London: Palgrave Macmillan.

Partnoy, F. 2009. Infectious Greed. How Deceit and Risk Corrupted Financial Markets. New York: PublicAffairs.

Pasquino, G. 1995. "Partitocrazia." in La Politica Italiana. Dizionario critico 1945-95, edited by G. Pasquino. Roma/Bari: Laterza.

Pasquino, G. 2000. "Political Development." in Italy since 1945, edited by P. McCarthy. Oxford: Oxford University Press.

Penati, A. 2005. "I Furbetti Del Lingotto E II Dodo Di Piazza Affari." La Repubblica, September 23. Retrieved 22 June 2014 (http://ricerca.repubblica.it/repubblica/archivio/repubblica/2005/09/23/fu rbetti-del-lingotto-il-dodo-di.html).

Piga, G. 2001. Derivatives and Public Debt Management. Zurich, New York: International Securities Market Association - Council for Foreign Relations.

Preda, A. 2009. Framing Finance. The Boundaries of Markets and Modern Capitalism. Chicago: University of Chicago Press.

Puledda, V. 1998a. "Da Confindustria E Assonime No Alla Nuova Opa Di Draghi." La Repubblica, January 28. Retrieved 22 June 2014 (http://ricerca.repubblica.it/repubblica/archivio/repubblica/1998/01/28/d a-confindustria-assonime-no-alla-nuova-opa.html).

Puledda, V. 1998b. "Rivoluzione in Borsa Piccoli Soci Più Protetti." La Repubblica, February 21. Retrieved 22 June 2014 (http://ricerca.repubblica.it/repubblica/archivio/repubblica/1998/02/21/ri voluzione-in-borsa-piccoli-soci-piu-protetti.html).

Quaglia, L. 2011. “The Ebb and Flow' of Euroscepticism in Italy." South European Society and Politics 16(1):31-50.

Rampini, F. 1997. "Il Popolo Telecom." La Repubblica, October 29. Retrieved 22 June 2014

(http://ricerca.repubblica.it/repubblica/archivio/repubblica/1997/10/29/ilpopolo-telecom.html).

Repubblica, La. 1998. "Opa, La Soglia Non Scenderà Sotto II 30\% - La Repubblica.it." La Repubblica, November 2. Retrieved 22 June 2014 (http://ricerca.repubblica.it/repubblica/archivio/repubblica/1998/02/11/o pa-la-soglia-non-scendera-sotto-il.html). 
Repubblica, La. 2007. “Consob, Condanne E Multe a Ifil per L'Equity Swap' Sulla Fiat." La Repubblica, February 13. Retrieved 22 June 2014 (http://www.repubblica.it/2006/09/sezioni/economia/fiat-8/consobifil/consob-ifil.html).

Repubblica, La. 2013. "Ifil-Exor, Condannati Gabetti E Grande Stevens In Appello Un Unno E Quattro Mesi." La Repubblica, February 21. Retrieved 22 June 2014 (http://www.repubblica.it/economia/2013/02/21/news/ifilexor_attesa_la_sentenza_da_torino_gabetti_no_a_onta_di_una_conda nna-53089707/).

Roe, M. J. 1994. Strong Managers, Weak Owners: The Political Roots of American Corporate Finance. Princeton NJ: Princeton University Press.

Sbragia, A. 2001. "Italy Pays for Europe: Political Leadership, Political Choice, and Institutional Adaptation." in Transforming Europe. Europeanization and Domestic Change, edited by M. Green Cowles, J. Caporaso, and T. Risse. Ithaca: Cornell University Press.

Scalfari, E. 1997. "Gli Incesti Del Capitale." La Repubblica.it, August 29. Retrieved 22 June 2014 (http://ricerca.repubblica.it/repubblica/archivio/repubblica/1997/08/29/gli -incesti-del-capitale.html).

Scalfari, E. 1998. "Grandi Famiglie E Mercato Globale." La Repubblica. Retrieved 22 June 2014 (http://ricerca.repubblica.it/repubblica/archivio/repubblica/1998/02/08/gr andi-famiglie-mercato-globale.html).

Scognamiglio, C. 1990. Rapporto Al Ministro Del Tesoro. Commissione per II Riassetto Del Patrimonio Mobiliare Pubblico E per Le Privatizzazioni. Roma: Istituto Poligrafico e Zecca dello Stato.

Segreto, L. 1997. "Models of Control in Italian Capitalism from the Mixed Bank to Mediobanca, 1894-1993." Business and Economic History 26(2):649-61.

Segreto, L. 1998. "Italian Capitalism between the Private and Public Sectors, 1933-1993." Business and Economic History 27(2):455-68.

Segreto, L. 2008. "Il Caso Mediobanca." in Storia d'Italia. La Banca, Annali 23, edited by C. Bermond, A. Cova, M. Moioli, and S. La Francesca. Torino: Einaudi.

Silva, P. 2008. In the Name of Reason. Technocrats and Politics in Chile. University Park: Pennsylvania State University Press.

Stockhammer, E. 2008. "Some Stylized Facts on the Finance-Dominated Accumulation Regime." Competition and Change 12(2):184-202. 
Sum, Ngai-Ling, and Bob Jessop. 2013. Towards a Cultural Political Economy: Putting Culture in Its Place in Political Economy. Cheltenham: Edward Elgar Publishing.

Swan, E. J. 1999. Building the Global Market, a 4000 Year History of Derivatives. London: Kluwer Law International.

Van Appeldoorn, B., and L. Horn. 2007. "The Marketisation of European Corporate Control: A Critical Political Economy Perspective." New Political Economy 12(2):211-35.

Wigan, D. 2008. "A Global Political Economy of Derivatives: Risk, Property and the Artifice of Indifference." Dphil thesis, University of Sussex.

Wigan, D. 2009. "Financialisation and Derivatives: Constructing an Artifice of Indifference." Competition \& Change 13(2):157-72.

Zaloom, C. 2006. Out of the Pits. Traders and Technology from Chicago to London. Chicago: University of Chicago Press. 